\title{
Water managed properties of apple and pear trees based on lysimeters
}

\author{
Péter Riczu ${ }^{1}$ - Nikolett Szőllősi ${ }^{1}$ - János Tamás ${ }^{1}$ - József Zsembeli ${ }^{2}$ \\ ${ }^{1}$ University of Debrecen Centre of Agricultural and Applied Economic Sciences Faculty of Agricultural and Food Sciences and \\ Environmental Management, Department of Water- and Environmental Management, 4032 Debrecen, Böszörményi út 138. Hungary \\ ${ }^{2}$ Karcag Research Institute of the Centre for Agricultural and Applied Economic Sciences, 5300 Karcag, Kisújszállási út 166. Hungary \\ riczu@agr.unideb.hu
}

Keywords: transpiration, leaf area index, water balance, apple tree model

SUMMARY

A significant proportion of the aboveground green and dry weight of the plant is constituted by foliage. The canopy is an important factor of plant growth. On the one hand, the canopy absorbs solar energy, which is necessary for photosynthesis; on the other hand, it accumulates the nutrients absorbed by the roots, and most of the water-loss occurs through the foliage. The determination of the full canopy is not an easy target. In our research, we developed a measurement method to determine the leaf area. With the parameters of the examined tree (leaf length and maximum width) and the data of the ADC AM 100 leaf area scanner, we determined the k-value, with which we can easily and fast evaluate the leaf surface. Furthermore, we defined from the water balance of compensation lysimeters the cumulative transpiration of fruit trees and the efficiency of water use of trees. From the examined trees were made a 3D depiction, which show the shape, branching and the location of trees.

\section{INTRODUCTION}

Presently in Hungary about 100,000 hectares of orchards can be found, of which apple is cultivated on one of the largest areas. The total area of apple and pear orchards is more than 45,000 ha. The data of the Central Statistics Office show that $28 \%$ of the apple and pear orchards could be irrigated, but only $21 \%$ are. Horticulture is a water demanding sector, as high quality fruit-growing is difficult without proper irrigation. Furthermore, on some horticultural farms, there is either no irrigation applied or the techniques used are improper. There are several experiments going on around the world to develop methods of irrigation, which draw different technology combinations for water and energy saving micro-irrigation. One of the biggest professional challenges of the coming years is to develop water resource management for apple and pear trees. First, we have to identify the water norm of the trees in the different phenological stages, the irrigation turns, the watering technology and the transpiration surface.

\section{LITERATRE}

HUZSVAI et al. (2005) determined that leaves were good environmental indicators and thus suitable for phenometrical measurements. Other features of leaves include their capability for use in the detection of environmental impacts. Mainly, the leaf area, e.g. the horizontal and vertical leaf surface size and geometry are important. The size and the location of the leaves determine at what radiation the plant's ability to absorb is. The size of leaves we can express with leaf area (LA). In orchard, if increases the leaf area, increases just a certain limit of the luminous efficiency, until the mutual shading of the plants does not inhibit it (BALÁZS et al., 1989).

$$
L A=\frac{s_{\max }-h_{\max }}{K}=k \cdot\left(s_{\max } \cdot h_{\max }\right)
$$

where: $s_{\max }$ is the maximum width of leaf, $h_{\max }$ is the maximum length of leaf, $K$ is the species and species characteristic splitting factor, $k$ is the species and species characteristic multiplier factor (HUZSVAI et al., 2005). Several researchers - including POLSTER AND REICHENBACH (1958) - typed the leaf shape of plants, and defined the $\mathrm{K}$ and $\mathrm{k}$ values.

In an orchard, a plant's leaf area must not be determined only in absolute terms, but compared with the growing area (T) also. The rate of two values called leaf area index (LAI), which is leaf area $\left(\mathrm{m}^{2}\right)$ per $1 \mathrm{~m}^{2}$ soil surface. The LAI is the most suitable index in the cultivation practice for the plant mass (SZÁSZ, 1988; BALÁZS et al., 1989).

$$
L A I=\frac{L A}{T}\left(\mathrm{~m}^{2} / \mathrm{m}^{2}\right)
$$

LAI - as biophysical status - is in a close relationship with the amount of the biomass, with the photosynthesis and transpiration scale (NEMANI and RUNNING, 1989). Size and number of leaves determine the leaf area (LA). Several factors influence amount of leaves in the trees. The number of leaf produced is reduced by water stress, nutrient deficiencies and is under hormonal control. Some researchers investigated the number of leaves and growing parameters, which develop on the new shoots under controlled environment 
conditions (ABBOTT, 1984; JOHNSON and LAKSO, 1985; LINDHAGEN, 1996). Maximal value of LAI among genetic limits - determinates several environmental and agronomic factors. Environmental factors: rate of temperature and precipitation far the plant requires, and the soil characteristic, thus rate and amount of available nutrients. Agronomic factors: density of crop, nutrient supply, irrigation, etc (HUZSVAI et al., 2005).

The leaf area index changes according to species, stage of development, methods of cultivation and density of crop. WAGENMAKERS (1989) found that leaf area per tree of apples and pears decreased linearly with planting density. VERHEIJ (1972) showed that with apple the leaf area per tree declined with increasing planting density even with unpruned trees, and was accompanied by a relative suppression of lateral growth in the lower parts of the trees.

Several publications deal with the determinate of LAI. These measurements primarily determine the LAI of the field crops, while in an orchard just little time determinate the leaf area index. For assign of the LAI evolve and spread some methods. Making leaf imprint is the most ancient method to determine leaf area. It gives a very precise result, but it is quite time consuming. (BOGNÁR, 2003). Among traditional methods for in situ leaf area determination the calculation-, the weighing- and the planimetric methods are used the most frequently (ROSS, 1981). ANDERSON (1981) used a fisheye optic camera and calculated the LAI from the cover of the sky in the photo. Leaf area can also be calculated by means of a solar radiation sensor (HUNKÁR, 1984). Automatic leaf area measuring devices are also available nowadays. The measurement is fast and precise with these electronic meters and the leaves do not have to be removed (BOGNÁR, 2003). Nowadays remote sensing methods are applied widespread to investigate large land fields and orchards. Within these methods the status of certain vegetation can be determined based on the reflectance spectra of the chlorophyll (Tamás and Nagy 2009). The Normalized Difference Vegetation Index (NDVI) is used to determine the leaf area, the quantity of green biomass, the chlorophyll content and the water content of the plant tissue (TUCKER, 1979; CIHLAR et al., 1991, SELLERS et al., 1992, GOWARD et al., 1994), which based on reflectance values of leaves.

The transpiration rate is also determined by the leaf temperature and the available moisture content of the soil. Transpiration is increasing if more water is available in the soil: in case of optimal water supply apple trees transpirated more water and the conductance of the stomas increased (ALLEYNE et al., 1989; GOWING et al., 1990; FRENANDEZ et al., 1997). During the day the water potential of apple and pear trees is decreasing with the increasing transpiration. GOODE and HIGGS (1973) observed the lowest water potential in noontime. LANDSBERG et al. (1975) and FERNANDEZ et al. (1997) examined apple and pear trees under droughty and control conditions. They concluded that the closing of the stomas is an effective physiological control that reduces the rate of transpiration.

\section{MATERIAL AND METHODS}

On $1^{\text {st }}$ March 20102 pear (Bosc kobak and William's) and 1 apple varieties (Regal Prince) were planted in 3 replications into 9 lysimeters with compensation system of the lysimeter station of the Karcag Research Institute of the Research Institutes and Study farm of the Centre for Agricultural and Applied Economic Sciences of the University of Debrecen. Each lysimeter has a surface area of $0.8 \mathrm{~m}^{2}$ and depth of $2 \mathrm{~m}$. The permanently maintained groundwater level is at the depth of $90 \mathrm{~cm}$ serving as the water supply (subsurface irrigation) of the trees in dry periods. The soil surface was covered with black plastic (polyethylene) sheet that stopped evaporation but let the natural precipitation infiltrate into the soil.

On $29^{\text {th }}$ September 2010 the leaves were collected from each tree. The leaves from the lower branches were separately collected from the leaves of the upper branches, and also the fallen leaves were gathered. The scanning of the leaves was carried out in the laboratory of the Department of Water- and Environmental Management of the Centre for Agricultural and Applied Economic Sciences of the University of Debrecen. The leaf areas were determined by means of a device called Area Meter 100 (AM 100) developed by the Analytical Development Company.

In our experiment we investigated if knowing the length and the width of the leaf, is it possible to calculate the area by using a multiplying factor. After measuring the length and the longest width of the leaf, we multiplied these two parameters getting the area of a square $\left(\mathrm{A}_{\text {square }}\right)$ that included the area of the leaf. Then the leaf was scanned, so we got the exact area of it $\left(\mathrm{A}_{\text {leaf }}\right)$. Dividing the two areas, we get a multiplying factor $(\mathrm{k})$ that can be used for further calculations.

$$
k=\frac{A_{\text {leaf }}}{A_{\text {square }}}
$$

To determine the rate of transpiration and the water use efficiency of the trees, we processed the data gained by the lysimeter measurements. Transpiration was calculated according to the following equation:

$$
T=P-D+I
$$

where $T$ is the transpiration of the tree $(\mathrm{mm}), P$ is the amount of natural precipitation $(\mathrm{mm}), D$ is the drainage water $(\mathrm{mm})$ flowing out through the compensation system and $I$ is the subsurface irrigation water flowing in from the compensation system. 
We modelled all of the trees on the lysimeter station in 3D. The apple and pear trees were drawn using Google SketchUp 7.1. On the base of construction of trees was that we measured length of each branch in all directions, and drawn according to axes. The software is compatible with Google Earth, thus the terrain can be imported. Then we placed the trees on Google Earth.

\section{RESULTS AND DISCUSSION}

The apple and pear tree leaves collected at the end of the final phenological state were scanned and the total and the average leaf areas were determined. On the base of the data it can be established that the pear variety William's $\left(3.24 \mathrm{~cm}^{2}\right)$ had the smallest, while apple variety Regal Prince $\left(4.97 \mathrm{~cm}^{2}\right)$ had the largest average leaf size under the given climatic and edaphic conditions.

Further calculations were done in order to determine if we can find a „,k" multiplying factor for the in situ prediction of the leaf area of a tree.

It could be established that the k-values were the smallest in the case of the apple variety Regal Prince (0.271) which shows longer but narrower leaf shapes comparing to the shape of the Bosc kobak (0.284) or William's (0.28) leaves. Among the investigated fruit tree varieties William's had the most leaves (798) its relatively high k-value is the sign of roundish leaf shape. Variety Bosc kobak had the smallest difference in the number of leaves among the replications.

Calculating the leaf area for $1 \mathrm{~m}^{2}$ the LAI can be determined. Among the investigated varieties variety William's has the largest value of LAI.

In order to characterize the water use of the fruit trees, the transpiration of them was compared. As the investigated period was extremely wet, no subsurface irrigation water flew into the soil through the compensation system, but drainage waters were regularly collected. The water balances of the lysimeters were positive as the input by natural precipitation resulted in saturated state in the soil all over the investigated period with even regular deep percolation water. Hence the transpiration of the trees could be calculated as the difference between the natural precipitation and the drain waters (Figure 1.).

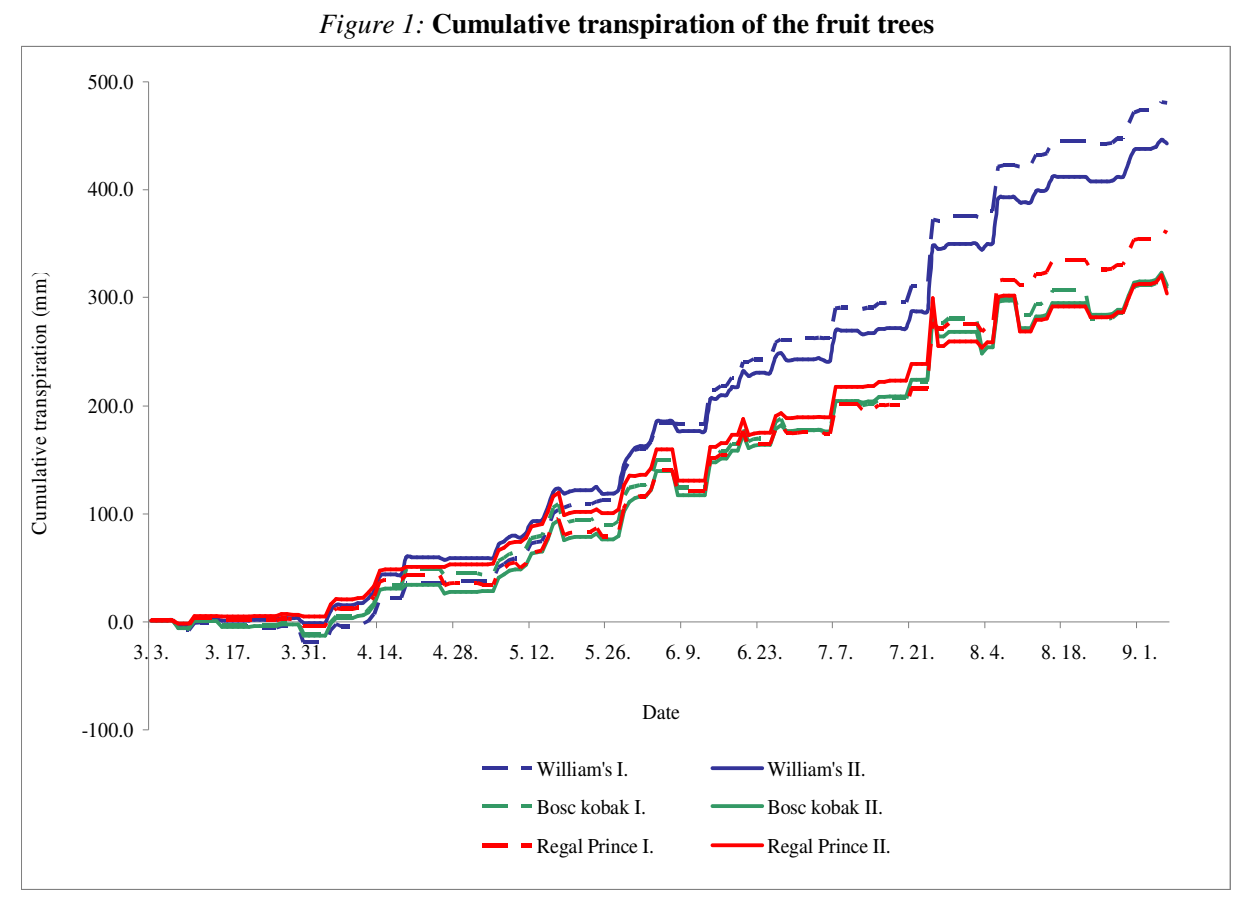

On the basis of the cumulative values of transpiration, it can be established that, in the initial growing phases, no differences could be detected among the trees. From May, some differences could be identified, indicating the differences in the speed of leaf growth characteristic to the different varieties. The highest differences in transpiration started to materialize when the trees reached the full development of their leaves. The highest transpiration values were detected in the case of the variety William's, while not inconsiderable differences could be determined between the varieties Bosc kobak and Regal Prince.

The water use efficiency values were also determined for the investigated fruit trees. This index shows how much water was used by the plant for transpiration from the total water input. As the amounts of drain water were the lowest in the case of variety William's, the highest transpiration and water use characterised this variety: the water use efficiency was above $80 \%$, while $50-60 \%$ was characteristic for the other two varieties. 


\section{CONCLUSIONS}

One of the main problems of in situ determination of leaf area is that the price of accurate devices is high. The advantages of the calculation method we used are as follows: it is fast, non-invasive and variety-specific. It provides the possibility of good estimation of the leaf area by measuring only the length and width of some leaves and calculating the $\mathrm{k}$-value from them.

After the development of their full foliage, considerable differences could be determined in the water balance of the lysimeters planted with the three fruit tree varieties. On the basis of the water use efficiency indexes, we established how much water was used by the trees to generate their own tissues from the total water input.

\section{REFERENCES}

Abbott D.L. (1984): The Apple Tree: Physiology and Management. London: Grower Books.

Allayne V.-Larsen F. E.-Higgins S. S. (1989): Water relations of container-grown, virus tested and common apple (Malus domestica Borkh) rootstocks. Scientia Horticulturae 38, pp. 117-129

Anderson M. C. (1981): The geometry of leaf distributions in some south-eastern Australian forests ,J. Agric. Meteorol. 25, pp. 195-205.

Balázs S.-Ackerl I.-Bittsánszky J.-Farkas J.-Fehér B.né,-Filius I.-Gyúrós J.-Hodossi S.-Hódosy S.-Kapeller K.-Nagy J.-Szabó I.-Szalay F.-

Tarjányi F.-Terbe I.-Velich I.-Zatykó F.-Zatykó L. (1989): Handbook of vegetable growers. Mezögazda Kiadó, Budapest.

Bognár K. R. (2003): Changes of the radiation balance in forests. Diploma work, 2003. NYME Erdömérnöki Kar

Boldizsár A. (2007): Evaporation and microclimate studies in the Balaton lake reeds. PhD thesis. Keszthely. pp. 27

Cihlar J., St-Laurent L., Dyer J. A. (1991): Relation between the normalized difference vegetation index and ecological variables. Remote Sensing of Environment. 35. pp. 279-298

Fernandez R. T.-Perry R. L.-Flore J. A. (1997): Drought response of young apple tree rootstocks. II. Gas exchange, chlorophyll fluorescence, water relations, and leaf abscisic acid. J. Amer. Soc. Hort. Sci. 122:841-848.

Goode H. G.- Higgs K. H. (1973): Water potential-water content relationships in apple leaves. J. Exp. Bot. 30:965

Goward S. N., Haemmrich K. F., Waring R. H. (1994): Visible-near infrared spectral reflectance of landscape components in western Oregon. Remote Sensing of Environment. 47. pp. 190-203.

Gowing D. J.-Davies W. J.-Jones H. G. (1990): A positive root-sourced signal as an indicator of soil drying in apple, Malus domestica Borkh. J. Exp. Bot. 41: 1535-1540

Hunkár, M. (1984): Relationship of solar radiation and plants. (mainly the photosynthetically active radiation for penetrate and utilized in the maize. ELTE PhD thesis.

Huzsvai L.-Rajkai K.-Szász G. (2005): Agro-ecological models. Electronic textbook in frame of the Ministry of Education and Higher Education Textbooks and Textbook support. Centre for Agricultural Science University of Debrecen, Debrecen

Johnson R.S.-Lakso A.N. (1986): Carbon balance model of a growing apple shoot. II. Simulated effects of light and temperature on long and short shoots. Journal of the American Society for Horticultural Science 111: 164-169

Landsberg J. J.-Beadle C. L.-Biscoe P. D.-Butler D. R.-Davidson B.-Incoll L. D.- James G. B.-Jarvis P. G.-Martin P. J.-Neilson R. E.-Powell D. B. B.-Slack E. M..-Thorpe M.R.-Turner N. C.-Warrit B.-Watts W. R. (1975): Diurnal energy, water and $\mathrm{CO}_{2}$ exchanges in an apple (Malus pumila) orchard. J. Applied Ecol. 12:659-684

Lindhagen (1996): Model analysis of leaf unfolding rate in Malus domestica Borkh. Scientia Horticulturae, Volume 67, Issues 1-2, November 1996., pp. 65-78

Nemani R. R.-Running S. W. (1989): Testing a theoretical climate-soil-leaf area hydrologic equilibrium of forests using satellite data and ecosystem simulation. Agricultural and Forest Meteorology Volume 44, Issues 3-4, January 1989, pp. 245-260

Polster H.-Reichenbach H. (1958): Bestimmung von Blattflächen in situ durch lineare Messungen. Biol. Zentralblatt. 77, 265-277

Ross J. K. (1981): The radiation regime and architecture of plant stands. Nederlands: Junk Publishers, The Hague. pp. 391

Sellers P. J., Berry J. A., Collatz G. J., Field C. B., Hall F. G. (1992): Canopy reflectance, photosynthesis and transpiration. III. A re-analysis using improved leaf models and a new canopy integration scheme. Remote Sensing of Environment. 42. pp. 1-30.

Szász G. (1988): Agro meteorology, Mezögazdasági Kiadó, Budapest, 462 p.

Tamás, J., Nagy, A. (2009): Green vegetation evaluation based on NDVI and field measurements. [In: Celkova, A. (ed.) Proceedings of peerreviewed contributions, Transport of water, chemicals and energy in the soil-plant-atmosphere system] Institute of Hydrology, Slovak Academy of Sciences, Bratislava, 665-670.

Tucker C. J. (1979): Red and photographic infrared linear combinations for monitoring vegetation. Remote Sensing of Environment. 8. pp. 127-150.

Verheij E. W. M. (1972): Competition in apple, as influenced by Alar sprays, fruiting, pruning and tree spacing. PhD thesis. Wageningen.

Wagenmakers P. S. (1989): High-density planting system trial with pear. 4. International Symposium on Research and Development on Orchard and Plantation Systems, Dronten (Netherlands), 29 Aug - 2 Sep 1988 